\title{
Problems and Countermeasures of Practice Teaching Quality Management in Colleges and Universities
}

\author{
Li Zhe \\ School of Economics and Management, Tianjin Institute of Urban Construction \\ Tianjin, China \\ lizheteacher@126.com
}

\begin{abstract}
Practice teaching plays an important role in the reform of higher education. So, a more standardized, routine, systemized and scientific quality management should be realized, otherwise, the imbalance between construction and management lead to a practice teaching just in name, leaving the objective of producing talents un-achieved. To strengthen the quality management on practice teaching is the key for colleges and universities to produce applied talents. Current problems existing in such aspects as funds, teachers' qualities, supervision and evaluation in the process of colleges' and universities' practice teaching are analyzed in this paper; some suggestions and countermeasures in terms of quality criteria, curriculum system, management system, construction of teachers, practice platform, supervision mechanism and so on are proposed to optimize the teaching quality, hoping to help colleges and universities produce more applied talents.
\end{abstract}

Keywords- Colleges and universities; Practice teaching; Quality management

\section{STATUS QUO AND MAJOR PROBLEMS IN THE PRACTICE TEACHING IN COLLEGES AND UNIVERSITIES}

\section{A. Obvious Shortage in Funding}

To be a first-class or high-level university, many colleges and universities desperately strive for new subjects and conducting scientific researches because these two efforts are the sign showing a sound and quick development and are also a chief way to obtain more funds. The problem of "two systems" between scientific research and teaching still exists. Theoretical teaching have been laid more emphasis than on practice teaching because of high practice expenditure and management cost in many colleges and universities; and in many of them, the practice funds are reduced rather than be improved, resulting in low morale in teachers and students, outdated teaching contents, poor experiment and practice conditions and shortage in places for experiment and practice.

\section{B. Incompetent Practice Teaching Teachers}

There is the "inherent deficiency" in teachers" practice ability in colleges and universities. They pays more attention on teaching theoretical knowledge, with insufficient consciousness and incentives to improve their practice ability. The construction of laboratories and practice bases are lagged behind because of the enrollment expansion, which limits the practice teaching, leading to ineffective utility of and improvement in teachers' available practice ability and their ability being not up to the advanced level in society. In addition, achievements in scientific researches instead of teaching quality and practice ability are taken into consideration in teachers' assessment and professional title evaluation. Even though teachers have the awareness to improve their practice ability from the very beginning, they would immediately divert their concentration to scientific researches with the absence of incentive mechanism for practice ability.

\section{Different Cognitions on the Combination of Industry,} University and Research

The practical combination of university and industry is targeted to obtain funds from enterprises and achievements in scientific researches (in enterprises' eyes, it is the universities' task to cultivate talents).Most of the enterprises do not want to accept student interns anymore because economic benefit is their first concern and students' internship can hardly bring any economic benefit and even can affect the routine production, for example, too more students in the workshop can easily lead to chaos or production accidents. Even though some accept student interns, they would make many requirements and limitations. Therefore, the combination of industry-university-research cannot provide an opportunity to practice for students in a real sense.

\section{Imperfect Monitoring and Evaluating System for Practice Teaching Quality}

A reasonable practice teaching quality monitoring and evaluating system is vital for specifying teachers' and students' behaviors, guaranteeing an orderly practice teaching and improving teaching quality. Frankly speaking, a complete monitoring and evaluating system has been worked out in theory teaching, while there is not such a one for practice teaching. A standard assessment method has not been established in some colleges and universities, or the old mode is used to make monitor and control index and assessment method, resulting in the absence of multi-level, multi-dimension and multi-mode monitoring and evaluating system; along with students' insufficient awareness of the importance of practice teaching, the effect of practice teaching is far from people's expectations. The improvement in practice teaching quality is hindered by the unscientific and un-objective evaluation on practice teaching with the absence of scientific, comprehensive and standard criteria. 


\section{COUNTERMEASURES FOR IMPROVING PRACTICE TEACHING IN COLLEGES AND UNIVERSITIES}

\section{A. To Establish Quality Standard for the Whole Process of Practice Teaching in Colleges and Universities}

Quality standard is the foundation and basis of teaching quality guarantee system and norms for all practice activities which are supposed to be complied with during practice teaching process. The organizational management of practice teaching process includes making and carrying out teaching plans, managing teaching process and supporting process, assessment, construction of courses; practice teaching resources coverage, funds, construction of textbooks, teachers and facilities and conditions of practice should be managed according to some standard. First of all, quality standard for the whole process of practice teaching should be worked out according to educational objectives, which is the only way to realize a real scientific practice teaching and the fundamental foundation of ensuring a high teaching quality. The teaching quality can be guaranteed through a standard in controlling, supervision and evaluation.

\section{B. To Establish Ability-oriented Practice Teaching Curriculum System}

In colleges and universities, the concept of "abilityoriented" curriculum should be adopted; practice ability should be the focus and the combination of knowledge and practice skills should be paid attention; their educational objectives and curriculum provision should serve for producing applied talents with high professional quality and proficient practical skills to highlight the core position of practice ability in curriculum system. Foundation and objectives of cultivating skilled talents can be worked out according to changes of demand for talents in the comprehensive analysis on society and employment market. According to educational objectives, curriculum system should be updated constantly to achieve the objective of producing talents with skills and adapting to social development.

\section{To Improve Teachers' Practice Teaching Ability}

In terms of teacher assessment, a suitable system laying equal emphasis on scientific achievement and practice achievement and an incentive mechanism for teachers' participation in practice should be set up. In terms of teachers' professional title evaluation, practice skills should be made one of requirement for promotion to improve teachers' practice ability. Teachers should be sent to the first line in enterprises to enrich practice experience and improve practice skills. Besides, teachers should be inspired to attend licensing tests through which they can improve their expertise knowledge structure and get a license to have more practice opportunities.

\section{To Set up a Team of Managing Practice Teaching}

The team of managing practice teaching can transfer teaching decisions into specific practical teaching activities. The point is to establish and perfect guarantee measures, to establish a coordinated system of organizing practice teaching and making clear the relations, works and responsibilities of each organizing level. Principals should take the lead of a forceful leading; education administration department and practice teaching management department should bear the responsibility of managing, coordinating and examination; teaching management departments at each school should organize and implement; instructing teachers team should give instructions, examine the management. The relations between each organization's responsibility and power should be made clear and a close and interdependent unity should be formed in the whole practice teaching to provide a forceful safeguard for improving teaching quality.

\section{E. To Build Project Practice Platform through the Combination of Industry-University-Research}

In new situations, such cooperation in colleges and universities needs to concern over each participant"industry", "university" and "research" and consider all parties related. So the major parties - universities or colleges, enterprises, governments and research institutes should be "banged together" to activate people's enthusiasm in cultivating talents. Meanwhile, in the process of carrying the cooperation forward, the extension of practice bases off campus must be paid attention and the construction of campus engineering centers and laboratories should be paid more attention. Make most use of opportunity of leading transnational enterprises' investment promotion in national key colleges and universities to join hands with them in building engineering centers and labs, which can not only make up for the universities' deficient investment on facilities, but also facilitate teachers and students.

\section{F. To Establish a Practice Teaching Supervision Mechanism}

The supervision should cover the teaching quality of three levels: school-department-students, information feedbacks such as students' rating of teaching, teachers' evaluation of students; a comprehensive, diverse, multi-level and dimensional mechanism should be adopted to supervise and evaluate how well the teaching quality goes. The whole process of teaching and learning in enterprises must be monitored to ensure a high quality of off-campus practice classes; teaching management should be make scientific and standard to improve management level, teaching quality and colleges' and universities' effectiveness and achieve the objective of producing talents.

The management work of practice teaching in colleges and universities are massive and arduous, which means educator of higher education need to update their concept by starting from to strengthen the educational mode of producing applied talent in new era to boost the reform of practice teaching management; they should mobilize various forces from all works of life to participate in this effort and do some practical works, all of which can achieve some accomplishments. At present, there is still a long way to go for many colleges and universities to improve and optimize their management in practice teaching. Therefore, they need to learn the advanced management experience home and 
abroad and draw their own conclusions during their practice to improve.

\section{REFERENCES}

[1] Chai Xiuzhi, "Study on the "Diversified" Management modes of Practice Teaching Quality in Higher Vocational Colleges” [J] Science and Technology Innovation Herald, 2010.No14.

[2] Xv Liping, "Higher Vocational Technology Education: Re-study on Concept", [J] Heilongjiang Researches on Higher Education, 2007,10..
[3] Wu Zongkui, Discussions on Practice Teaching Quality Management System in Higher Vocational Colleges, [J] Journal of Sanmenxia Polytechnic, 2008,10.

[4] Lin Jian, "Discussions on Reforms by the Implementation of 'Plan of Producing Excellent Engineers'” [J] China Higher Education, 2010, (17).

[5] Bai Jing, Wang Xiaofang, "How to Improve Young Teachers Projects Practice Ability in Colleges and Universities" [J],Liaoning Education Research,2002(4):36-37.

[6] Wu Zhiyun, Wang Liping, Gao Xiaoping, "On Improving the Construction of Off-campus Practice Bases", [J] Research and Exploration in Laboratory, 2007, 26 (5):95-97. 